\title{
寒冷地における住宅用給湯設備の効率性に関する研究 A STUDY ON EFFICIENCY OF HOT WATER SUPPLY SYSTEMS IN COLD CLIMATE AREA
}

\author{
小澤明也*，浅野良晴**，高村秀紀***，久保田敏史****，安 部祐 樹* \\ Akiya OZAWA, Yoshiharu ASANO, Hideki TAKAMURA, \\ Toshifumi KUBOTA and Yuuki ABE
}

\begin{abstract}
The authors investigated how to use three kinds of hot water supply systems which were condensing type gas water heater systems, $\mathrm{CO}_{2}$ heat pump water heater systems and residential gas engine co-generation systems (GE-CGS) in four detached houses of Nagano prefecture. GE-CGS was installed in house A and house B. Condensing type gas water heater systems were installed in house B and house $\mathrm{C} . \mathrm{CO}_{2}$ heat pump water heater systems were installed in house $\mathrm{C}$ and house $\mathrm{D}$.

We analyzed the energy efficiency of these systems. As a result, GE-CGS of house A was the highest in the annual energy efficiency, and it followed that $\mathrm{CO}_{2}$ heat pump water heater system of house $\mathrm{D}$ was the lowest.
\end{abstract}

Keywords : Hot water supply, City gas, Electricity, Energy efficiency 給湯，都市ガス，電気，エネルギ一効率

1. はじめに

\section{1 研究の背景}

日本の家庭部門でのエネルギー消費量は年々増加傾向にあり、家 庭用機器の省エネルギー化が進められている。住宅のエネルギー消 費量は、給湯分野が 30\%を占めるとされており ${ }^{1)}$ 、その省エネルギ 一化を図る為に、潜熱回収型ガス給湯器、 $\mathrm{CO}_{2}$ ヒートポンプ給湯機、 家庭用ガスエンジンコージェネレーションシステム (以下 GE-CGS と 略記) 等の高効率給湯設備が開発され、普及が促進されている。潜熱 回収型ガス給湯器は排気ガス中の潜熱を回収することで従来型に対 して高効率化した。また、電気をエネルギー源とする $\mathrm{CO}_{2}$ ヒートポ ンプ給湯機は、ヒートポンプ技術を導入することで高効率化を達成 した。そして、都市ガスを燃料にガスエンジンで発電し、発電時の 排熱を利用して熱供給を行う GE-CGS も実用化している。

これらの給湯設備は、一定の条件下で試験された定格効率により 高効率であることが示されているが、住民のライフスタイルの多様 化、外気温度等の外界気象条件によって、実使用下での効率と定格 効率とは異なることが予想される。

\section{2 研究概要及び既往研究}

本研究では、寒冷地に立地する戸建住宅に潜熱回収型ガス給湯器 と $\mathrm{CO}_{2}$ ヒートポンプ給湯機を設置し、切り替えて運転することで、 両給湯設備の年間エネルギー効率を明らかにする。 ${ }^{2)}$ ま、寒冷地
の戸建住宅に GE-CGS と潜熱回収型ガス給湯器を設置し、切り替えて 運転することで、両給湯設備の年間エネルギー効率を明らかにする。 3)さらに、寒冷地の戸建住宅における $\mathrm{CO}_{2}$ ヒートポンプ給湯機の年間 エネルギー効率を明らかにする。 ${ }^{2)}$ そて、これら 3 種の給湯設備 のエネルギー効率について効率性の検討を行う。

2009 年 4 月に施行された新しい住宅省エネ基準「住宅事業建築主 の判断の基準」4)では、実住宅における湯消費実態の調査に基づき、 実使用を反映させた試験方法を開発し、一般に普及している給湯設 備の実証実験を行っている。評価方法は 4 人家族の標準的な湯消費 を再現した修正 M1 モードを用いて、給湯設備の年間 1 次エネルギー 消費量を推計している。しかし、評価に用いている湯の消費パター ンは湯張りを行うことを基本としたものであるため、湯張りの頻度 が少ない住宅等は対象とせず、基準適用範囲が狭いものとなってい る。また、寒冷地・準寒冷地における効率についても実測などを含 めた検討が重要であると記述している。本論文では、寒冷地の実際 の湯消費状況における効率の基礎データに資するものとして効率性 の検討を行う。3 種の給湯設備における既存の知見として、GE-CGS の効率性は、清水ら ${ }^{5)}$ や木谷ら ${ }^{6)}$ が GE-CGS を設置した北海道・北陸・ 関東・関西・中国に立地する戸建住宅において実測調査を行い、熱 利用システム稼働効率等を定義し、発電利用効率と熱利用システム 稼働効率の関係を明らかにしている。潜熱回収型ガス給湯器の効率
* 信州大学大学院工学系研究科 大学院生

** 信州大学工学部建築学科, 信州大学山岳科学総合研究所 教授・工博

*** 信州大学工学部建築学科, 信州大学山岳科学総合研究所 准教授・博士 (工学)

**** (株)大林組 工修

(当時 信州大学大学院工学系研究科)
Graduate Student, Faculty of Eng., Univ. of Shinshu

Prof., Dept. of Architecture, Faculty of Eng., Univ. of Shinshu and Institute of Mountain Science, Univ. of Shinshu, Dr. Eng.

Assoc. Prof., Dept. of Architecture, Faculty of Eng., Univ. of Shinshu and Institute of Mountain Science, Univ. of Shinshu, Dr. Eng.

Obayashi Corporation, M. Eng. 
性は、中濱ら ${ }^{7)}$ が短時間出湯の割合が大きい世帯で効率は低下し、 特に追い焚きの効率が低いことを明らかにしている。しかし、給湯 設備の電力消費量による効率への影響については十分に検討されて いない。また $\mathrm{CO}_{2}$ ヒートポンプ給湯機の効率性は、高田ら ${ }^{8)}$ が $\mathrm{CO}_{2}$ ヒートポンプ給湯機を設置した全国 14 戸のモニタ住宅において実 測調査を行い、HPCOP 及びシステム COP の変動要因を検討している。

本研究では、GE-CGS の効率性に関して、エネルギー効率と日平均 外気温度及び家庭内消費電力割合との関係を明らかにする。潜熱回 収型ガス給湯器の効率性は、エネルギー効率と日平均外気温度及び 給湯設備における電力消費量との関係を明らかにする。また、 $\mathrm{CO}_{2}$ ヒートポンプ給湯機の効率性は、タンク効率、HP 稼働時出湯温度別 のエネルギー効率とタンク効率との関係を明らかにする。

\section{3 研究の目的}

本研究は、寒冷地の戸建住宅 3 棟と GE-CGS 及び太陽光発電システ ム（以下、PVS と略記）を設置した戸建住宅 1 棟を加えた計 4 棟を 対象に、GE-CGS、潜熱回収型ガス給湯器、 $\mathrm{CO}_{2}$ ヒートポンプ給湯機の 3 機種について実測する。そして、各住宅における消費湯量、熱需 要及び電力需要、各給湯設備のエネルギー消費量及び稼働状況を分 析する。また、給湯設備の出力エネルギーを投入エネルギーで除し たエネルギー効率を算出する。そして、寒冷地の給湯設備を高効率 で利用することを目的として、効率性の検討を行う。

\section{2. 計測対象住宅の概要}

計測対象住宅の概要を表 1 に示す。住宅 B 及び C では 2 種の給湯 設備を交互に切り替えて運転している。そして、住宅 D では $\mathrm{CO}_{2}$ ヒ ートポンプ給湯機を 2 年間計測したため、 1 年目と 2 年目を分けて 分析する。

\section{3. 計測概要}

\section{1 給湯設備の仕様}

住宅 A 及び住宅 B の GE-CGS の仕様を表 2 に示す。住宅 A の GE-CGS は給湯及び床暖房に対して熱出力し、住宅 B では給湯、床暖房及び 浴室暖房乾燥機に対して熱出力する。住宅 B 及び C の潜熱回収型ガ ス給湯器の仕様を表 3 に示す。住宅 B の潜熱回収型ガス給湯器は、 給湯、床暖房及び浴室暖房乾燥機に対して熱出力寸る。住宅 C 及び $\mathrm{D}$ の $\mathrm{CO}_{2}$ ヒートポンプ給湯機の仕様を表 4 に示す。

\section{2 給湯系統及び計測箇所}

計測対象住宅における給湯設備の系統図及び計測箇所を図 1〜図 4 に示す。住宅 B 及び C は、給湯配管、給水配管、風呂循環配管、 暖房循環配管にバルブを設置し、給湯設備の切り替えを行う。また、 各流量、温度、ガス消費量、電力消費量の計測は 1 分間隔で行う。

\section{3 計測期間}

各住宅における分析使用日数及び計測期間を表 5 に示す。分析す る際の季節区分は、 6 月から 8 月を夏期、9 月から 11 月と 3 月から 5 月を中間期、 12 月から 2 月を冬期とする。住宅 B は、GE-CGS の運 転を 2 週間、潜熱回収型ガス給湯器の運転を 1 週間として切り替え ている。住宅 C は、 $\mathrm{CO}_{2}$ ヒートポンプ給湯機及び潜熱回収型ガス給湯 器を 2 週間毎に切り替えている。 $\mathrm{CO}_{2}$ ヒートポンプ給湯機への切り替 え後の 1 週間は、学習期間として分析からは除外している。各給湯 設備の設定内容を表 6 に示す。
表 1 計測対象住宅の概要

\begin{tabular}{|c|c|c|c|c|c|}
\hline 住宅 & 給湯設備 & 所在地 & 延床面積 & 家族構成 & 備考 \\
\hline $\mathrm{A}$ & GE-CGS & 長野市 & $252 \mathrm{~m}^{2}$ & 6人 & 太陽光発電パネルを併設 \\
\hline \multirow{2}{*}{ B } & GE-CGS & \multirow{2}{*}{ 長野市 } & \multirow{2}{*}{$146 \mathrm{~m}^{2}$} & \multirow{2}{*}{ 4人 } & \multirow{2}{*}{ 給湯設備の切り替え運転云 } \\
\hline & 潜熱回収型ガス給湯器 & & & & \\
\hline \multirow{2}{*}{$\mathrm{C}$} & 潜熱可収型ガス給湯器 & \multirow{2}{*}{$\begin{array}{l}\text { 上高井郡 } \\
\text { 小布施町 }\end{array}$} & \multirow{2}{*}{$143 \mathrm{~m}^{2}$} & \multirow{2}{*}{ 5人 } & \multirow{2}{*}{ 給湯設備の切り替え運䡛云 } \\
\hline & $\mathrm{CO}_{2}$ ヒートポンプ給湯機 & & & & \\
\hline \multirow{2}{*}{ D } & \multirow{2}{*}{$\mathrm{CO}_{2}$ ヒートポンプ給湯機 } & \multirow{2}{*}{ 長野市 } & \multirow{2}{*}{$161 \mathrm{~m}^{2}$} & \multirow{2}{*}{ 4人 } & 計測1年目 \\
\hline & & & & & 計測2年目 \\
\hline
\end{tabular}

表 2 GE-CGS の仕様

\begin{tabular}{|c|c|c|c|c|}
\hline \multicolumn{5}{|c|}{ 住宅A及ひB } \\
\hline \multicolumn{2}{|c|}{$\begin{array}{l}\text { 発電ユニット } \\
\end{array}$} & \multicolumn{3}{|c|}{$\begin{array}{ll}\text { 貯湯ユニット } \\
\end{array}$} \\
\hline \multirow{2}{*}{$\begin{array}{l}\text { 発電出力 } \\
\text { 排熱出力 }\end{array}$} & \multirow{2}{*}{$\begin{array}{c}1 \mathrm{~kW} \\
2.8 \mathrm{~kW} \\
\end{array}$} & \multicolumn{2}{|c|}{ タンク容量 } & $140 \mathrm{~L}$ \\
\hline & & \multirow{3}{*}{ 加熱能力 } & 給湯 & 24 号 \\
\hline \multirow{4}{*}{ 定格効率 } & \multirow{4}{*}{$\begin{array}{c}\text { 発電20.3\% } \\
\text { 排熱56.9\% } \\
\text { (HHV) }\end{array}$} & & 追い焚き & $12 \mathrm{~kW}$ \\
\hline & & & 暖房 & $17 \mathrm{~kW}$ \\
\hline & & 最大消 & 霓電力 & $293 \mathrm{~W}$ \\
\hline & & 凍結防I & ヒータ & $184 \mathrm{~W}$ \\
\hline
\end{tabular}

表 3 潜熱回収型ガス給湯器の仕様

\begin{tabular}{|c|c|c|}
\hline & 住宅B & 住宅 $\mathrm{C}$ \\
\hline 給湯能力 & $2.2 \sim 24$ 号 & 2.8 8 28号 \\
\hline 暖房能力 & $\begin{array}{cc}11.6 \sim 22.4 \mathrm{~kW} & \text { 比例制御 } \\
2.44 \sim 0 \mathrm{~kW} & \text { ON-OFF制御 }\end{array}$ & - \\
\hline 定格効率 & 給湯95\%、暖房87\% & $95 \%$ \\
\hline 消費電力 & $290 \mathrm{~W}$ & $190 \mathrm{~W}$ \\
\hline
\end{tabular}

表 $4 \quad \mathrm{CO}_{2}$ ヒートポンプ給湯機の仕様

\begin{tabular}{|c|c|c|c|c|c|}
\hline \multicolumn{6}{|c|}{ 住宅C } \\
\hline \multicolumn{3}{|c|}{ ヒートポンプユニット } & \multicolumn{3}{|c|}{ 貯湯ユニット } \\
\hline \multirow{2}{*}{ 加熱能力 } & 定格 & 6. $0 \mathrm{~kW}$ & \multirow{2}{*}{\multicolumn{2}{|c|}{ タンク容量 }} & $460 \mathrm{~L}$ \\
\hline & 冬季高温 & 6. $0 \mathrm{~kW}$ & & & 4000 \\
\hline \multicolumn{2}{|c|}{ 定格効率 } & 4.6 & \multirow{4}{*}{ 消費電力 } & 熱交循環ポンプ & $11 \mathrm{~W}$ \\
\hline \multirow{2}{*}{ 消費電力 } & 定格 & $1.30 \mathrm{~kW}$ & & 風呂循環ポンプ & $105 \mathrm{~W}$ \\
\hline & 冬季 & $1.79 \mathrm{~kW}$ & & 積層ポンプ & $8 \mathrm{~W}$ \\
\hline \multicolumn{2}{|c|}{ 待機電力 } & $11 \mathrm{~W}$ & & 制御用 & $5 \mathrm{~W}$ \\
\hline \multicolumn{6}{|c|}{ 住宅D } \\
\hline \multicolumn{3}{|c|}{ ヒートポンプユニット } & \multicolumn{3}{|c|}{ 貯湯ユニット } \\
\hline \multirow[b]{2}{*}{ 加熱能力 } & 定格 & $6.0 \mathrm{~kW}$ & \multicolumn{2}{|c|}{ タンク容量 } & $430 \mathrm{~L}$ \\
\hline & 夏季高温 & 4. $5 \mathrm{~kW}$ & \multirow{5}{*}{ 消費電力 } & 循環ポンプ & $161 \mathrm{~W}$ \\
\hline \multicolumn{2}{|c|}{ 定格効率 } & $\frac{6.0 \mathrm{~kW}}{4.9}$ & & & \\
\hline \multirow{3}{*}{ 消費電力 } & 定格 & $1.22 \mathrm{~kW}$ & & 七一夕 & $96 \mathrm{~W}$ \\
\hline & 夏季 & $0.89 \mathrm{~kW}$ & & 制御用 & $20 \mathrm{~W}$ \\
\hline & 冬季 & $1.78 \mathrm{~kW}$ & & 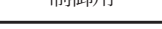 & \\
\hline
\end{tabular}
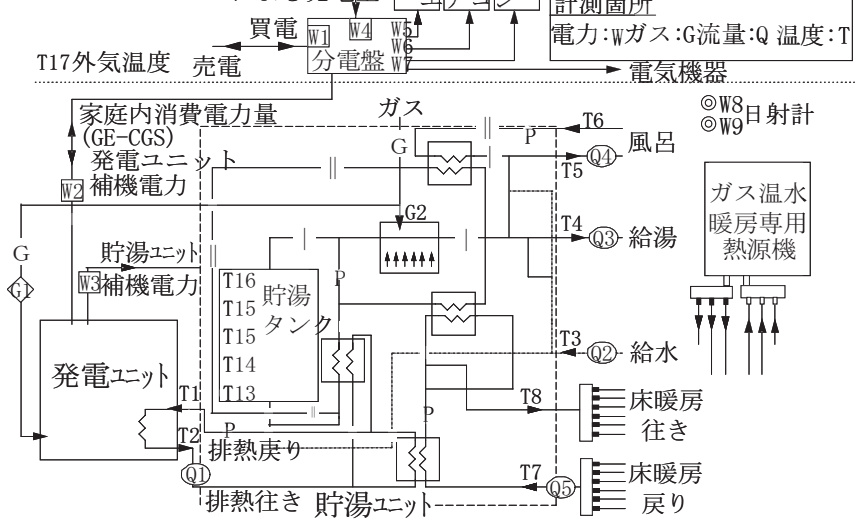

図 1 住宅 A における給湯設備の系統図及び計測項目

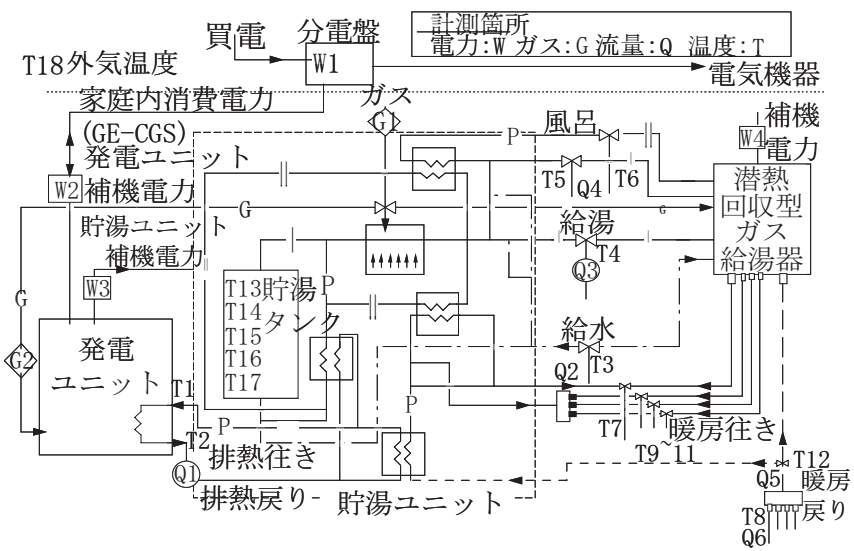

図 2 住宅 B における給湯設備の系統図及び計測項目 


\section{4. 住宅毎の熱需要及び電力需要}

\section{1 住宅毎の $40^{\circ} \mathrm{C}$ 換算消費湯量}

$40^{\circ} \mathrm{C}$ 換算消費湯量は、湯張り量、足し湯量、給湯量の合計であり、 追い焚きを含まない。季節毎の日積算 $40^{\circ} \mathrm{C}$ 換算消費湯量を図 5 に示 す。既往研究 ${ }^{9)}$ では全国の集合住宅と戸建住宅を含む 229 住戸で世 帯人数別の $40^{\circ} \mathrm{C}$ 換算消費湯量の平均値を明らかにしている。 4 人世 帯の住宅 B 及び D における年間の日積算 $40^{\circ} \mathrm{C}$ 換算消費湯量は、既往 研究の平均值 $448.2 \mathrm{~L}$ よりも少ない。また、 6 人世帯の住宅 A 及び 5 人世帯の住宅 C においては、既往研究 ${ }^{99}$ の平均值 536.7L よりも多 い。これは住宅 A 及びC の場合、住民が通年で湯張りしていたこと によるものと考える。

\section{2 住宅毎の熱需要}

追い焚き負荷割合とは、湯張り負荷に対する追い焚き負荷の比率 であり、追い焚き負荷割合 $R_{r h}$ を（1）式で表す。そして、季節毎の 日積算給湯負荷及び暖房放熱量、追い焚き負荷割合を図 6 に示寸。

$R_{r h}=\left(Q_{r h} / Q_{\text {bath }}\right) \times 100 \quad \cdots(1)$

住宅 A は床暖房を長時間使用していたため、冬期の床暖房放熱量 が増大している。住宅 B は、浴室暖房乾燥機に重点をおいて給湯設 の暖房機能を使用している。そして、住宅 B の夏期はシャワーだけ を使用しており、湯張りは行われていない。また、住宅 B の年間追 い焚き負荷率は 100\%超えている。これは、湯張りを行った際の残り 湯を、翌日に追い焚きすることによって再加熱し、入浴していたか らである。住宅 C の冬期における追い焚き負荷割合は、両給湯設備 ともに $40 \%$ を超えている。これは、住宅 B と同様に浴槽の残り湯を 追い焚きによって再加熱していたと考える。

\section{3 住宅毎の電力需要及び発電量}

住宅 $\mathrm{A}$ 及び $\mathrm{B}$ における日積算家庭内消費電力量、購入電力量及び 発電寄与率の季節変動を図 7 に示す。家庭内消費電力量とは、GE-CGS 及び PVS から家庭内へ供給される電力量を表す。発電寄与率とは、 住宅の全電力消費量に対する GE-CGS 及びPVS の家庭内消費電力量の 比率を表す。住宅 A の場合、家庭内消費電力量 (GE-CGS) が住宅の全 電力消費量の $31 \%$ を占めており、家庭内消費電力量 (PVS) も合わせ ると $52 \%$ である。家庭内消費電力量 (PVS) が減少する冬期において も、発電寄与率 (GE-CGS+PVS) は 50\%である。また、住宅 B の年間の 日積算家庭内消費電力量 (GE-CGS) は住宅 A に対して $3 \mathrm{kWh}$ 少ない。

\section{5. 給湯設備のエネルギー消費量及び稼働状況}

\section{1 給湯設備毎のガス消費量及び電力消費量}

給湯設備毎の日積算ガス消費量及び電力消費量の季節変動を図 8 に示す。給湯設備の電力消費量とは、各種ポンプ及び制御管理用、 凍結防止ヒータ等、給湯設備内における電力消費量の合計を表す。 GE-CGS の全ガス消費量に対して補助ボイラが占める割合は、住宅 A で 23\%であり、住宅 B では 21\%である。住宅 A、住宅 B、住宅 C のガ ス給湯設備の電力消費量は、冬期に増大している。これは、給湯設 備に内蔵されている凍結防止ヒータによるものと考える。

\section{2 GE-CGS 発電ユニットの稼働状況}

住宅 A 及び B における GE-CGS の稼衝状況を表 7 に示す。システム 内消費電力量とは、 $\mathrm{GE}-\mathrm{CGS}$ が発電した電力のうち、発電ユニット内 のヒータで熱に変換される電力量を表している。

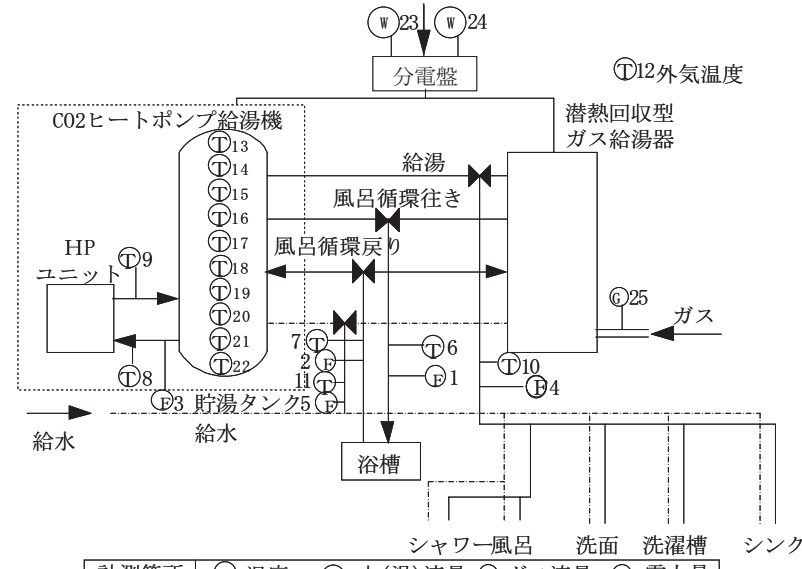

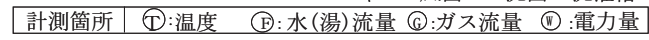

図 3 住宅 Cにおける給湯設備の系統図及び計測項目

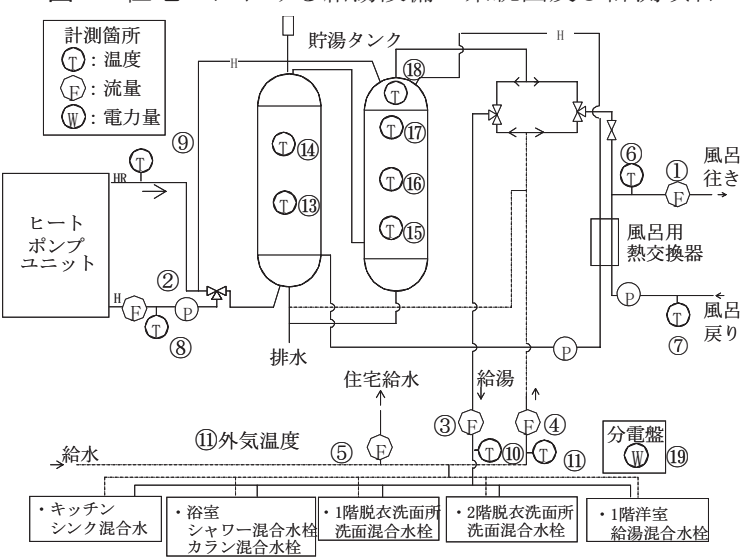

図 4 住宅 Dにおける給湯設備の系統図及び計測項目

表 5 各住宅における分析使用日数及び計測期間

\begin{tabular}{|c|c|c|c|c|c|c|}
\hline 住宅 & 給湯設備 & 分析使用日数 & $\begin{array}{l}\text { 湯張り } \\
\text { 日数 }\end{array}$ & \begin{tabular}{|c|} 
床暖房 \\
使用 \\
日数
\end{tabular} & $\begin{array}{l}\text { 浴容暖房 } \\
\text { 乾燥機 } \\
\text { 使用日数 }\end{array}$ & 計測期間 \\
\hline 住宅A & GE-CGS & 364 & 352 & 179 & - & $\begin{array}{l}\text { 2009年6月25日から } \\
\text { 2010年6月25日 }\end{array}$ \\
\hline \multirow[b]{2}{*}{ 住宅B } & GE-CGS & 219 & 32 & 31 & 13 & $\begin{array}{l}2009 \text { 年6月27日から } \\
2010 \text { 年6月25日 }\end{array}$ \\
\hline & $\begin{array}{l}\text { 潜熱回収型 } \\
\text { ガス給湯器 }\end{array}$ & 109 & 18 & 95 & 52 & $\begin{array}{l}2009 \text { 年6月27日から } \\
2010 \text { 年6月25日 }\end{array}$ \\
\hline \multirow[b]{2}{*}{ 住宅C } & $\begin{array}{l}\text { 潜熱热收收型 } \\
カ ゙ ス \text { 給湯器 }\end{array}$ & 153 & 116 & - & - & $\begin{array}{l}2007 \text { 年10月 } 2 \text { 日から } \\
\text { 2008年9月29日 }\end{array}$ \\
\hline & $\begin{array}{l}\mathrm{CO}_{2} \text { ヒート } \\
\text { ポンプ } \\
\text { 給湯機 }\end{array}$ & $\begin{array}{c}211 \\
\text { 学習期間除< } \\
(148)\end{array}$ & $\begin{array}{l}155 \\
(108)\end{array}$ & - & - & $\begin{array}{l}\text { 2007年10月 } 2 \text { 日から } \\
\text { 2008年9月 } 29 \text { 日 }\end{array}$ \\
\hline \multirow{2}{*}{ 住宅D } & \multirow{2}{*}{$\begin{array}{l}\mathrm{CO}_{2} \text { ヒート } \\
\text { ポンープ } \\
\text { 給湯機 }\end{array}$} & 344 & 247 & - & - & $\begin{array}{l}\text { 2008年6月1日から } \\
\text { 2009年5月 } 31 \text { 日 }\end{array}$ \\
\hline & & 292 & 226 & - & - & $\begin{array}{l}2009 \text { 年6月1日から } \\
2010 \text { 年4月12日 }\end{array}$ \\
\hline
\end{tabular}

表 6 各住宅における給湯設備の設定内容

\begin{tabular}{|c|c|c|c|c|}
\hline \multirow[b]{2}{*}{ 住宅 } & \multirow[b]{2}{*}{ 給湯設備 } & \multicolumn{2}{|c|}{ 設定温度 } & \multirow{2}{*}{ 備考 } \\
\hline & & & 給湯 & \\
\hline 住宅A & $\begin{array}{l}\mathrm{GE}-\mathrm{CGS} \\
\end{array}$ & $40^{\circ} \mathrm{C}$ & $411^{\circ} \mathrm{C}$ & - \\
\hline \multirow{2}{*}{ 住宅B } & GE-CGS & \multirow{2}{*}{$41^{\circ} \mathrm{C}$} & \multirow{2}{*}{$35^{\circ} \mathrm{C}$} & - \\
\hline & 潜熱笴収型ガス給湯器 & & & - \\
\hline \multirow[b]{2}{*}{ 住宅C } & 潜熱回收型ガス給湯器 & $42^{\circ} \mathrm{C}$ & $42^{\circ} \mathrm{C}$ & - \\
\hline & \multirow[b]{2}{*}{$\mathrm{CO}_{2}$ ヒートポンプ給湯機 } & $42^{\circ} \mathrm{C}$ & $42^{\circ} \mathrm{C}$ & $\begin{array}{c}\text { 沸き上げ湯量の設定は } \\
\text { 「多め連転」 }\end{array}$ \\
\hline 住宅D & & $40^{\circ} \mathrm{C}$ & $50^{\circ} \mathrm{C}$ & $\begin{array}{c}\text { 沸き上げ湯量の設定は } \\
\text { 「おまか地運転」 } \\
\text { 2年目夏期のみ 「少なめ運転 }\end{array}$ \\
\hline
\end{tabular}

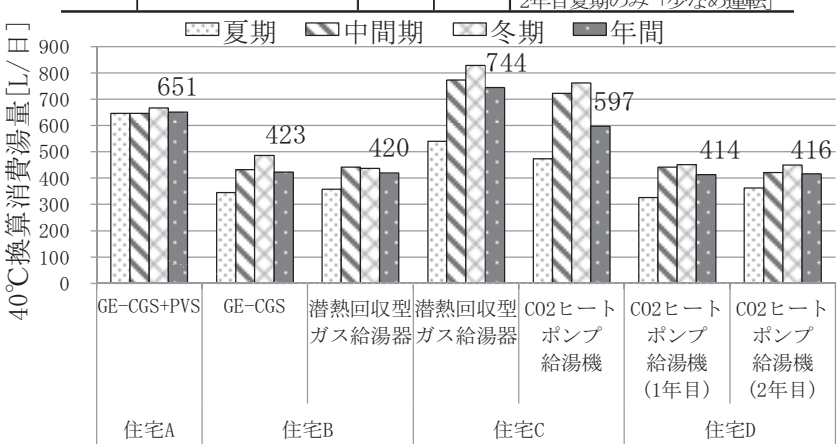

図 5 日積算 $40^{\circ} \mathrm{C}$ 換算消費湯量の季節変動 
そして、発電利用効率 $\eta_{\text {epg }}$ 、排熱・ヒータ回収効率 $\eta_{e e r} 、 \mathrm{GE}-\mathrm{CGS}$ 発電ユニット総合効率 $\eta_{G E-C G S u n i t}$ を (2)〜 (4) で示す。また、1 日の GE-CGS の総発電量に対する家庭内消費電力量 $(\mathrm{GE}-\mathrm{CGS})$ の割合を表 した、家庭内消費電力割合 $R_{G E-C G S, h o u s e}$ を(5) 式で示し、1 日の GE-CGS の総発電量を(6) 式で示す。

$\eta_{\text {epg }}=b \cdot W_{G E-C G S, \text { house }} / a \cdot G_{G E}$

$\eta_{e e r}=Q_{e e r} / a \cdot G_{G E}$

$\eta_{G E-C G S u n i t}=\eta_{\text {epg }}+\eta_{e e r}$

$R_{G E-C G S, \text { house }}=W_{G E-C G S, \text { house }} / W_{G E-C G S, \text { total }} \times 100$

$W_{G E-C G S, \text { total }}=1 \mathrm{kWh} \times \mathrm{h} \quad \cdots(6)$

$a=43.14[\mathrm{MJ} / \mathrm{kWh}]^{10)} \quad \mathrm{b}=3.6\left[\mathrm{MJ} / \mathrm{kWh}^{11)}\right.$

年間ガスエンジン稼働時間は、住宅 B より住宅 A が 3.2 時間長く 8. 45 時間である。既往研究 ${ }^{6}$ における関西及び関東都市部の 2 棟の 戸建て住宅の年間ガスエンジン稼働時間は、1 日当たり $5.2 \sim 5.5$ 時 間である。寒冷地では給湯及び暖房需要が増大寸るため、ガスエン ジン稼働時間が長時間になると考える。しかし、住宅 B では床暖房 を長時間使用していないため、給湯負荷が主な熱負荷となり、住宅 Aの様に長時間稼衝していない。

また、既往研究 ${ }^{6)}$ における年間家庭内消費電力割合は $70 \%$ ～ $71 \%$ であり、住宅 A での $85 \%$ は高い值である。しかし、住宅 B では年間 66\%と低い值である。よって、住宅 A では GE-CGS によって発電した 電力を高い割合で家庭内消費し、電力を有効利用していたことに対 し、住宅 B では GE-CGS によって発電した電力を家庭内で消費しきれ ず、発電ユニット内のヒータで熱に変換する割合が高い状況であっ たと考える。また、GE-CGS ユニット総合効率は、住宅 A 及び B 共に 定格值を満たしている。

\section{3ヒートポンプユニットの稼働状況}

住宅C 及びDの $\mathrm{CO}_{2}$ ヒートポンプ給湯機の稼働状況を表 8 に示す。 除霜運転時電力消費量は、HP 稼動時電力消費量に含まれている。 また、表の各項目は日平均值を表している。

住宅C 及びDにおける $\mathrm{CO}_{2}$ ヒートポンプ給湯機の年間 HPCOP は 2.23 〜2.64 である。住宅 D の 1 年目の夏期における HPCOP は 2.29 と中 間期よりも低い。そして、住宅 D の 1 年目の夏期の HP 稼働時平均出 湯温度は、 $86.75^{\circ} \mathrm{C}$ と高温である。また、 1 年目の夏期の $\mathrm{HP}$ 稼㗢時 平均入水温度も $48.79^{\circ} \mathrm{C}$ と高温である。よって、 1 年目の夏期では夕 ンク内の残湯が再度貯湯されていたと考える。

2 年目の計測では、夏期における $\mathrm{CO}_{2}$ ヒートポンプ給湯機の運転モ ードを「おまかせ」から「少なめ」へと変更した。運転モードの設 定変更を行った住宅 D の夏期における HPCOP は、設定変更前の 2.29 から 4.07 に上昇している。そして、年間 HPCOP は 2.23 から 2.63 に上昇している。また、住宅 D の 2 年目の夏期における $\mathrm{HP}$ 稼働時平 均出湯温度は 1 年目の $86.75^{\circ} \mathrm{C}$ から $70.68^{\circ} \mathrm{C}$ 低下している。そして、 住宅 D の 2 年目の夏期における HP 稼働時平均入水温度は、 1 年目の $48.79^{\circ} \mathrm{C}$ から $28.06^{\circ} \mathrm{C}$ 一低下している。

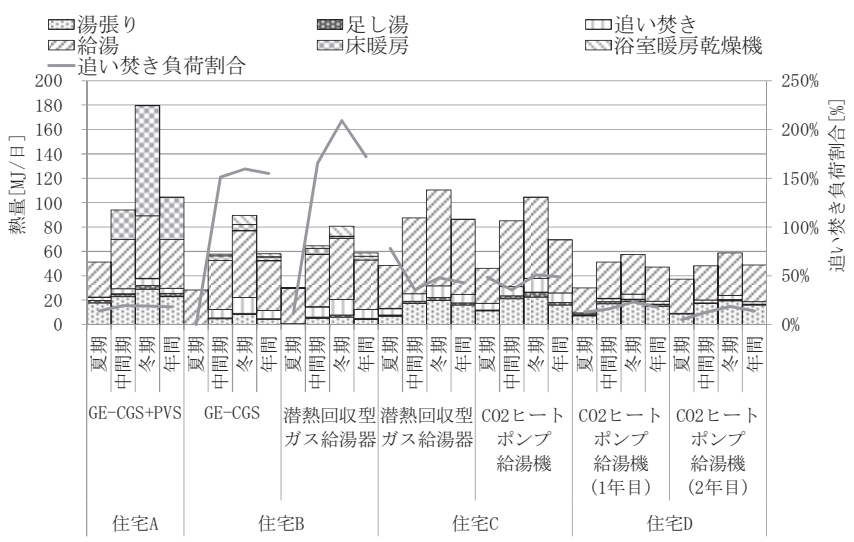

図 6 日積算給湯負荷、暖房放熱量及び 追い焚き負荷割合の季節変動

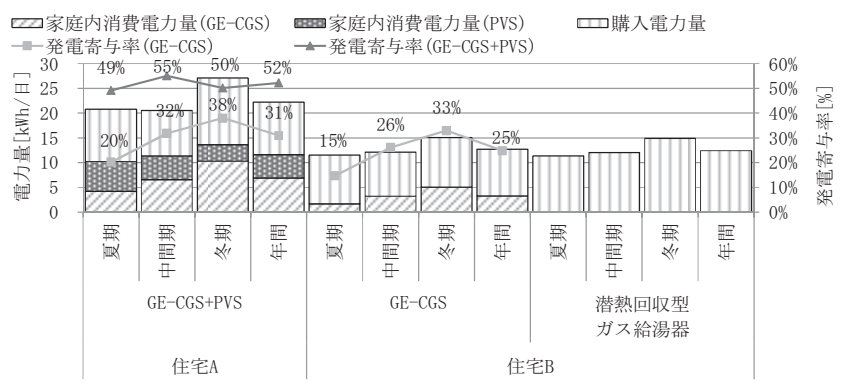

図 7 日積算家庭内消費電力量、購入電力量 及び発電寄与率の季節変動

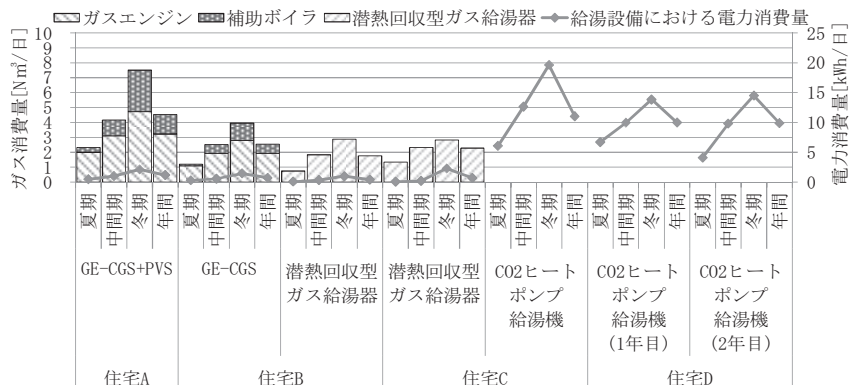

図 8 日積算ガス消費量及び電力消費量の季節変動

表 7 住宅 A 及び B における GE-CGS の稼働状況

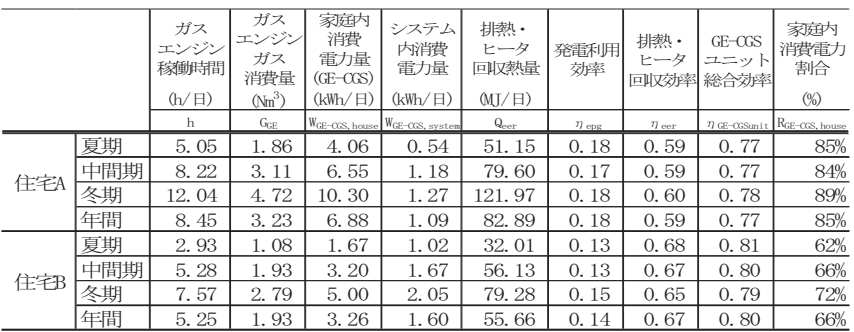

表 8 住宅 C 及び D の $\mathrm{CO}_{2}$ ヒートポンプ給湯機の稼働状況

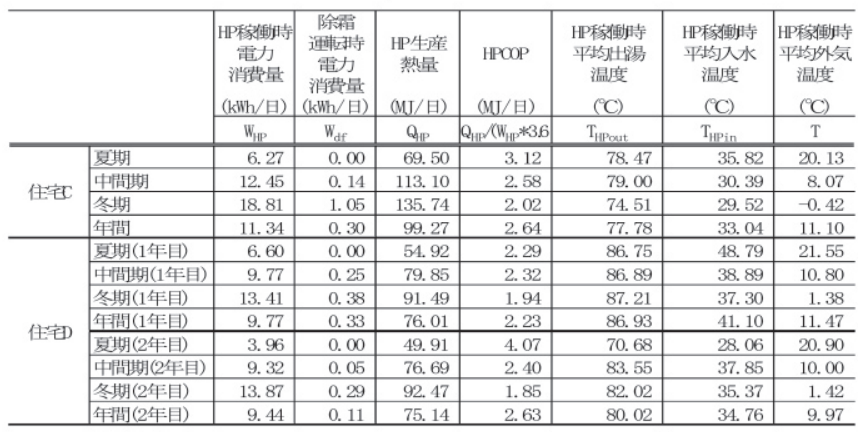




\section{6. 給湯設備の効率性に関する検討}

6. 1 エネルギー効率の算出

\section{1.11 次エネルギー効率の算出}

GE-CGS の 1 次エネルギー効率 $\eta_{G E-C G S 1}$ を(7) 式に示し、潜熱回収型 ガス給湯器の 1 次エネルギー効率 $\eta_{C G W H 1}$ を(8) 式に示す。また、 $\mathrm{CO}_{2}$ ヒートポンプ給湯機の 1 次エネルギー効率 $\eta_{\mathrm{CO}_{2} \mathrm{HP1}}$ を(9) 式に示す。

1 次エネルギー効率の季節変動を図 9 に示す。年間 1 次エネルギ 一効率は、住宅 A の GE-CGS が 0.87 と最も高い值であり、住宅 D の $\mathrm{CO}_{2}$ ヒートポンプ給湯機が 0.49 と最も低い值である。そして、季節 毎の 1 次エネルギー効率は、住宅 D における $\mathrm{CO}_{2}$ ヒートポンプ給湯 機の 2 年目の夏期が 1.10 と最も高い。

また、全ての給湯設備において冬期の 1 次エネルギー効率が最も 低いが、計測対象住宅の中では住宅 A の GE-CGS の 0.85 が最も高い 值である。

\section{1.22 次エネルギー効率の算出}

GE-CGS の 2 次エネルギー効率 $\eta_{G E-C G S 2}$ を(10) 式に示し、潜熱回収 型ガス給湯器の 2 次エネルギー効率 $\eta_{C G W H 2}$ を(11) 式に示す。また $\mathrm{CO}_{2}$ ヒートポンプ給湯機の 2 次エネルギー効率 $\eta_{\mathrm{CO}_{2} \mathrm{HP} 2}$ を(12) 式に示す。

2 次エネルギー効率の季節変動を図 10 に示す。住宅 $\mathrm{A}$ 及び B にお ける GE-CGS の 2 次エネルギー効率は季節変動が小さく、年間では $0.63 \sim 0.65$ である。また、 $\mathrm{CO}_{2}$ ヒートポンプ給湯機の年間 2 次エネ ルギー効率は 1.33 1.89である。

\section{2 GE-CGS と潜熱回収型ガス給湯器の 1 次エネルギー効率 \\ 6. 2. 1 住宅 B の GE-CGS と潜熱回収型ガス給湯器における 1 次エネルギー効率の比較}

住宅 B の GE-CGS と潜熱回收型ガス給湯器の 1 次エネルギー効率に ついて、夏期・中間期・冬期・年間で有意水準 $5 \%$ の平均の差の検 定 ${ }^{10)}$ を行う。夏期・中間期・年間のエネルギー効率には差がみられ、 冬期の 1 次エネルギー効率には差があるとはいえない。

\section{2 . 2 住宅 Bにおける給湯設備の熱出力及び電力出力の合計} 熱量と給湯設備の全エネルギー消費量との関係

住宅 B の GE-CGS 及び潜熱回収型ガス給湯器の運転期間を給湯 のみ出力している期間と、給湯と暖房を出力している期間に 分類する。そして、それぞれの期間における $\mathrm{GE}-\mathrm{CGS}$ 及び潜熱 回収型ガス給湯器の熱出力及び電力出力の合計熱量と給湯設 備の全エネルギー消費量との関係を図 11 に示す。熱出力及 び電力出力の合計熱量とは、 GE-CGS の場合は熱出力と電力出力 の合計出力を表しており、潜熱回収型ガス給湯器は熱出力のみを表 している。また、給湯設備の全エネルギー消費量とは、給湯設 備のガス消費量のエネルギー換算值と電力消費量の 1 次エネルギー 換算值の合計を表している。

給湯のみ出力している期間において(1)の GE-CGS の回帰直 線と (2)の潜熱回収型ガス給湯器の回帰直線は、熱出力及び電力 出力の合計熱量が正の範囲で交わることはない。しかし、給 湯と暖房を出力している期間における(3)の GE-CGS の回帰直 線は、(4)の潜熱回収型ガス給湯器の回帰直線と熱出力及び電力 出力の合計熱量が $98.52 \mathrm{MJ}$ の点で交わる。これは、熱出力及 び電力出力の合計熱量が $98.52 \mathrm{MJ} /$ 日を超えると潜熱回収型 ガス給湯器の効率を $\mathrm{GE}-\mathrm{CGS}$ が上回ることを表している。
エネルギー効率の算出

1 エネルギー効率の算出式

$\eta_{G E-C G S 1}=\frac{Q_{h w}+Q_{s p}+W_{G E-C G S, \text { house }} \cdot c}{\left(G_{G E-C G S}+G_{B U B}\right) \cdot a+W_{G E-C G S A U X S} \cdot c}$

$\eta_{C G W H 1}=\frac{Q_{h w}+Q_{s p}}{G_{C G W H} \cdot a+W_{C G W H A U X S} \cdot c}$

$\eta_{\mathrm{CO}_{2} \mathrm{HP1}}=\frac{Q_{h w}}{W_{\mathrm{CO}_{2} \mathrm{HP}} \cdot \mathrm{c}}$

2 次エネルギー効率の算出式

$\eta_{G E-C G S 2}=\frac{Q_{h w}+Q_{s p}+W_{G E-C G S, \text { house }} \cdot b}{\left(G_{G E-C G S}+G_{B U B}\right) \cdot a+W_{G E-C G S A U X S} \cdot b}$

$\eta_{C G W H 2}=\frac{Q_{h w}+Q_{s p}}{G_{C G W H} \cdot a+W_{C G W H A U X S} \cdot b}$

$\eta_{\mathrm{CO}_{2} \mathrm{HP2}}=\frac{Q_{h w}}{W_{\mathrm{CO}_{2} \mathrm{HP}} \cdot b}$

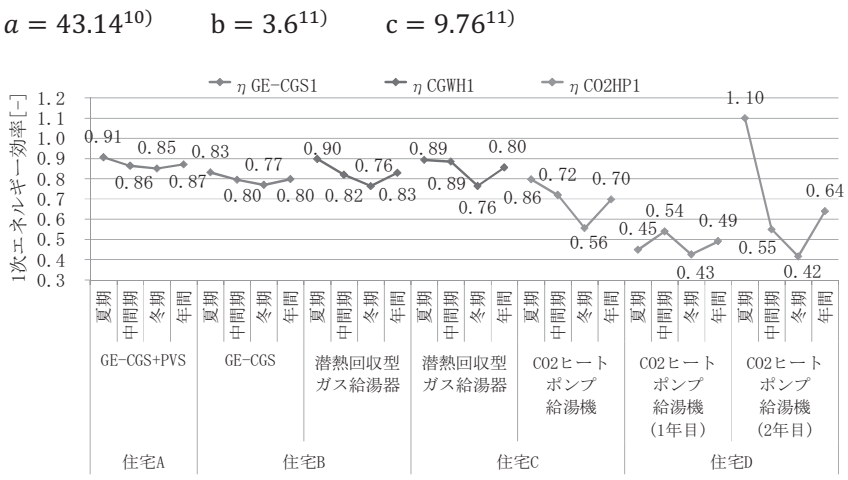

図 91 次エネルギー効率の季節変動

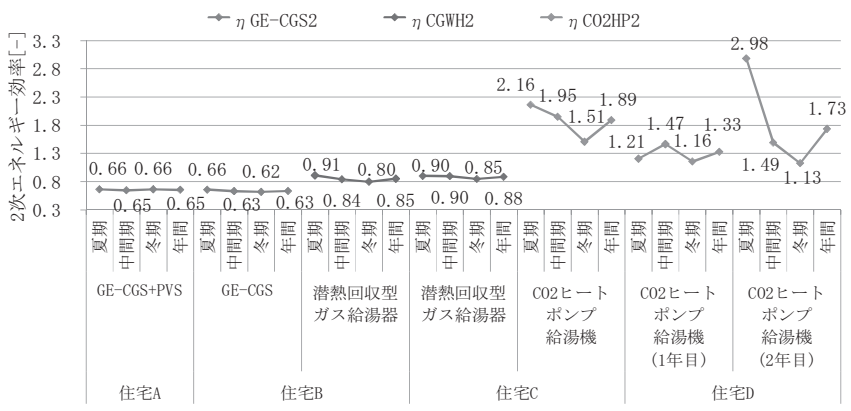

図 102 次エネルギー効率の季節変動

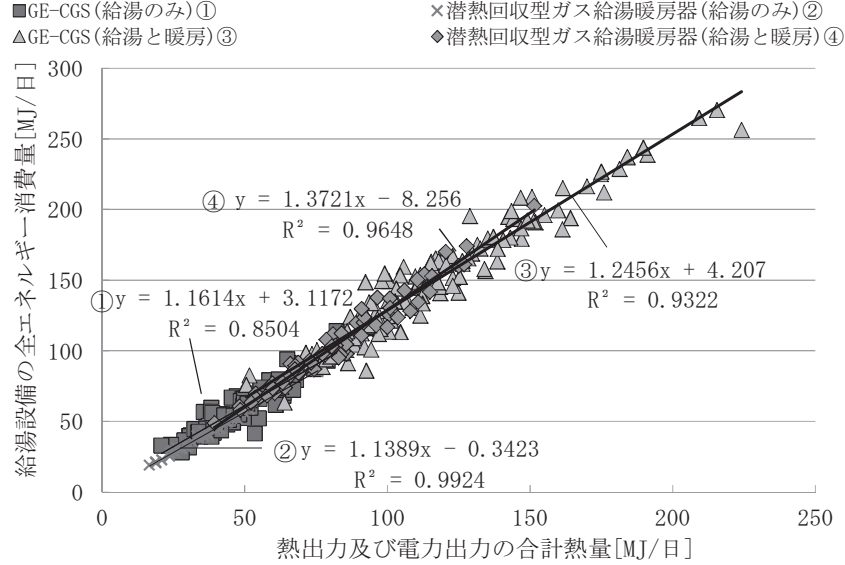

図 11 住宅 B の GE-CGS 及び潜熱回収型ガス給湯器における熱出力 及び電力出力の合計熱量と給湯設備の全エネルギー消費量の関係 
6. 3 GE-CGS の1 次エネルギー効率における効率性の検討

6. 3. 11 次エネルギー効率と日平均外気温度との関係

住宅 A 及び B の GE-CGS における 1 次エネルギー効率と日平均 外気温度との関係を図 12 に示す。住宅 A 及び B の 1 次エネルギー効 率について母分散の比の検定を有意水準 $5 \%$ で行う ${ }^{12)}$ 。住宅 A 及び B の 1 次エネルギー効率の分散に差があるとはいえない。住宅 A 及び B の 1 次エネルギー効率を同一母集団からの標本として扱う。GE-CGS の 1 次エネルギー効率と日平均外気温度の相関係数は 0.21 と小さい。 また、1 日の中で貯湯を使いきらずに翌日へ繰り越した場合、繰り 越した当日の 1 次エネルギー効率は低くなるが、翌日の 1 次エネル ギー効率は繰り越した貯湯を使用できるため高くなり、見かけ上 1.0 以上の值がみられる。

\section{3.21 次エネルギー効率と家庭内消費電力割合との関係}

住宅 $\mathrm{A}$ 及び B の GE-CGS における 1 次エネルギー効率と家 庭内消費電力割合との関係を図 13 に示す。

GE-CGS の 1 次エネルギー効率と家庭内消費電力割合の相関 係数は 0.54 と正の相関がみられる。住宅 Aにおける GE-CGS の家庭内消費電力割合は、住宅 B に対して高い值であること から、住宅 A の GE-CGS は高効率で稼働していたと考える。

\section{3.31 次エネルギー効率の重回帰分析}

GE-CGS の 1 次エネルギー効率を目的変数にとり、日平均 外気温度及び家庭内消費電力割合を説明変数として重回帰 分析を行う。分析方法は、ステップワイズ法を用いる。GE-CGS の 1 次エネルギー効率に対する重回帰式を表 9 に示す。そし て、分析結果を表 10 に示す。算出した重回帰式の重相関係 数は 0.64 であり、決定係数は 0.41 である。また、家庭内消 費電力割合の標準化係数は日平均外気温度の標準化係数よ り高い。GE-CGS の 1 次エネルギー効率の効率性として、外 気温度によるエネルギー効率への影響は小さく、家庭内消費 電力割合の影響が大きいと考える。

\section{4 潜熱回収型ガス給湯器における効率性の検討}

\section{4. 1 1 次エネルギー効率と日平均外気温度の関係}

住宅 B 及び C の潜熱回収型ガス給湯器の 1 次エネルギー効率と日 平均外気温度との関係を図 14 に示す。潜熱回収型ガス給湯器の 1 次エネルギー効率と日平均外気温度との関係には、二次多項式の当 てはまりが良く、相関係数は 0.78 と強い負の相関がみられる。 GE-CGS の 1 次エネルギー効率と日平均外気温度との相関係数は小さ い值であるが、潜熱回収型ガス給湯器と日平均外気温度との相関係 数は大きいことが明らかとなった。

\section{4. 21 次エネルギー効率と給湯設備の電力消費量の関係}

住宅 B 及び C の潜熱回収型ガス給湯器の 1 次エネルギー効率と給 湯設備の電力消費量との関係を図 15 に示寸。潜熱回収型ガス給湯器 の 1 次エネルギー効率と給湯設備の電力消費量との関係には、二次 多項式の当てはまりが良く、相関係数は-0.80 と強い負の相関がみ られる。これは、外気温度が低下した際に、給湯設備に内蔵された 凍結防止ヒータの電力消費量が増大したことによるものと考える。

\section{6. $5 \mathrm{CO}_{2}$ ヒートポンプ給湯機における効率性の検討 \\ 6. 5. 1 タンク効率}

残湯・ヒートロスの影響を評価う; する指標として、湯張り負荷、 足し湯負荷、追い焚き負荷、給湯負荷の合計熱量をヒートポンプに

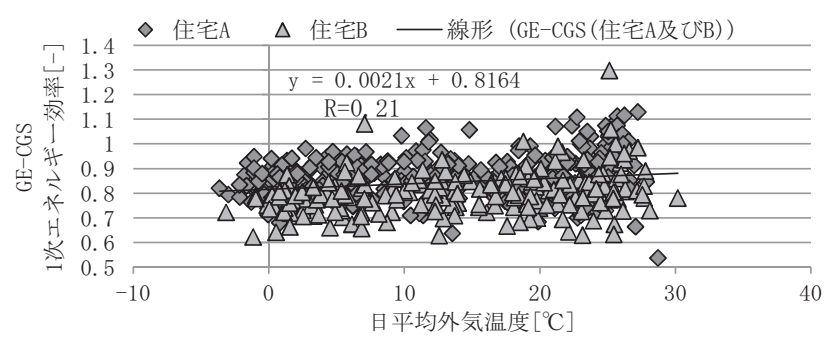

図 $12 \mathrm{GE}-\mathrm{CGS}$ の 1 次エネルギー効率と日平均外気温度との関係

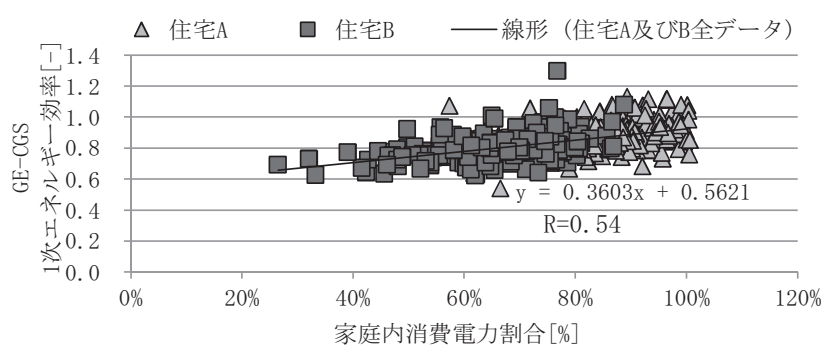

図 $13 \mathrm{GE}-\mathrm{CGS}$ の 1 次エネルギー効率と家庭内消費電力割合との関倸

表 9 GE-CGS の 1 次エネルギー効率の重回帰式

\begin{tabular}{|c|c|}
\hline 重回帰式 & $\mathrm{Y}=3.60 \times 10^{-3} \mathrm{X}_{1}+0.41 \mathrm{X}_{2}+0.47$ \\
\hline 変数 & $\mathrm{Y}:$ :エネルギー効率 $\mathrm{X}_{1}$ : 日平均外気温度 $\mathrm{X}_{2}$ : 家庭内消費電力割合 \\
\hline
\end{tabular}

表 10 GE-CGS の 1 次エネルギー効率の重回帰分析結果

\begin{tabular}{|c|c|c|c|c|}
\hline 重相関係数 $: \mathrm{R}$ & 決定係数 $: \mathrm{R}^{2}$ & 調整済み $\mathrm{R}^{2}$ & $\begin{array}{c}\text { 推定值の } \\
\text { 標準誤差 }\end{array}$ & データ数 \\
\hline \hline 0.64 & 0.41 & 0.41 & 0.07 & 583 \\
\hline
\end{tabular}

\begin{tabular}{|c|r|r|r|}
\hline 説明変数 & 非標準化係数 & 標淮化係数 & t值 \\
\hline \hline 日平均外気温度 & $3.60 \times 10^{-3}$ & 0.358 & 10.9 \\
\hline 家庭内消費電力割合 & 0.410 & 0.621 & 18.9 \\
\hline 定数 & 0.470 & & 25.1 \\
\hline \multicolumn{2}{|r|}{}
\end{tabular}

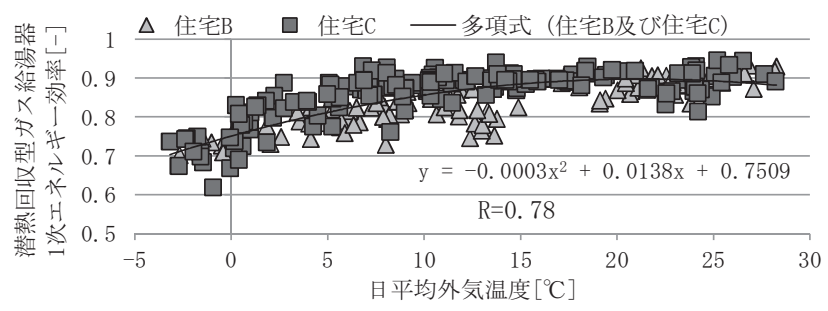

図 14 潜熱回収型ガス給湯器の

1 次エネルギー効率と日平均外気温度との関係

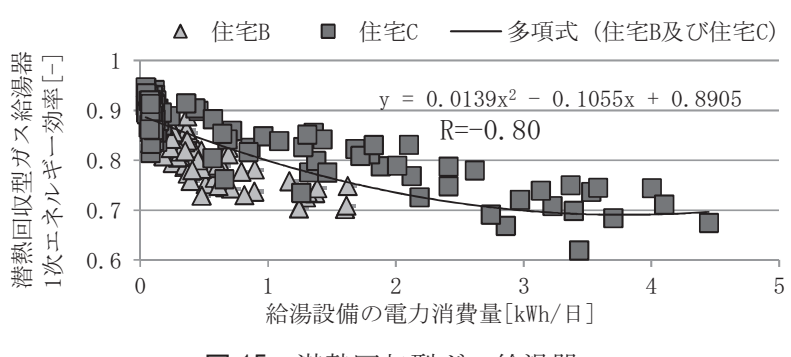

図 15 潜熱回収型ガス給湯器の

1 次エネルギー効率と給湯設備の電力消費量との関係

よる生産熱量で除したタンク効率を用いる。タンク効率の季節変 動を図 16 に示す。住宅 Cの場合は、夏期から冬期にかけてタンク効 率が増加しているが、住宅 D の場合は増加していない。 
よって、住宅 C では、冬期において給湯負荷が増加したため、タ ンク内の残湯が減少していたが、住宅 D では冬期においてもタンク 内の残湯が多く、タンク効率が増加していない。また、住宅 D の 2 年目の夏期におけるタンク効率は、運転モードの設定変更を行った ことによって 1 年目の 0.53 から 0.77 に増大している。

\section{5.21 次エネルギー効率とタンク効率との関係}

夏期における $\mathrm{HP}$ 稼働時平均出湯温度別の 1 次エネルギー効率と夕 ンク効率との関係を図 17 に示す。HP 稼働時平均出湯温度とは、七 ートポンプユニットからの出湯温度の平均值を表している。また、 図において 1 日の中で貯湯を使いきらずに翌日へ繰り越した場合、 繰り越した当日のタンク効率は低くなるが、翌日のタンク効率は高 くなり、見かけ上 1.0 以上の值がみられる。住宅 Cの夏期における 1 次エネルギー効率とタンク効率には、相関係数 0.90 の強い正の相 関がみられる。また、住宅 D の 1 年目及び 2 年目の夏期における 1 次エネルギー効率とタンク効率には、共に強い正の相関がみられる。 住宅 D の 2 年目の夏期における運転モードの設定変更を行った(3)の 期間は、 $\mathrm{HP}$ 稼働時平均出湯温度が $60^{\circ} \mathrm{C}$ 以上 $65^{\circ} \mathrm{C}$ 以下の範囲となり、 エネルギー効率が増加している。住宅 D の 2 年目の夏期における HP 稼働時平均出湯温度が 1 年目に対して低下したことにより、タンク 内の残湯を減少させ、1 次エネルギー効率が増加したと考える。

\section{7. まとめ}

本研究では、寒冷地の戸建住宅における給湯設備を高効率で利用 するために、GE-CGS、潜熱回収型ガス給湯器、 $\mathrm{CO}_{2}$ ヒートポンプ給湯 機の 3 機種を対象に実測調查を行った。そして、エネルギー効率を 算出し、給湯設備毎に効率性の検討を行った。

・年間 1 次エネルギー効率は、住宅 A の GE-CGS が最も高く、住宅 D の $\mathrm{CO}_{2}$ ヒートポンプ給湯機が最も低い結果である。冬期のエネルギ 一効率についても、住宅Aが 0.85 と高効率で稼働していた。よって、 住宅 A の GE-CGS が最も高効率で利用できたと考える。

・住宅 B において GE-CGS と潜熱回収型ガス給湯器の 1 次エネルギー 効率の比較を行い、冬期には差があるとはいないことを明らかにし た。また、GE-CGS の 1 次エネルギー効率は、日平均外気温度による 影響が小さく、家庭内消費電力割合の影響が強いことを明らにした。 よって、外気温度が低下寸る寒冷地においては、他の機種に対して GE-CGS は高効率で稼働することができると考える。しかし、発電し た電力を家庭で有効に消費できないと、潜熱回収型ガス給湯器の方 が高効率で稼働すると考える。

・ $\mathrm{CO}_{2}$ ヒートポンプ給湯機の実測によって、夏期においてもエネルギ 一効率は低下してしまうことが明らかとなった。住宅 D の夏期にお いてタンク効率が低下していたことから、タンク内の残湯が多いこ とが明らかとなった。タンク内の残湯が夏期における効率低下の要 因となっていたと考える。また、夏期の効率低下は運転モードの変 更によって、対処できることを明らかにした。よって、寒冷地にお いて給湯需要が低下寸る夏期には運転モードを「少なめ」に変更し、 残湯を減らす対処を行うことが高効率利用となる。

今後は、実用化段階に達した家庭用燃料電池コージェネレーショ ンシステムの実住宅における実測調査を行い、本研究で調查を行っ た 3 機種を含め、寒冷地における高効率給湯設備の効率性及び省工 ネルギー性についてさらに分析を行っていく。

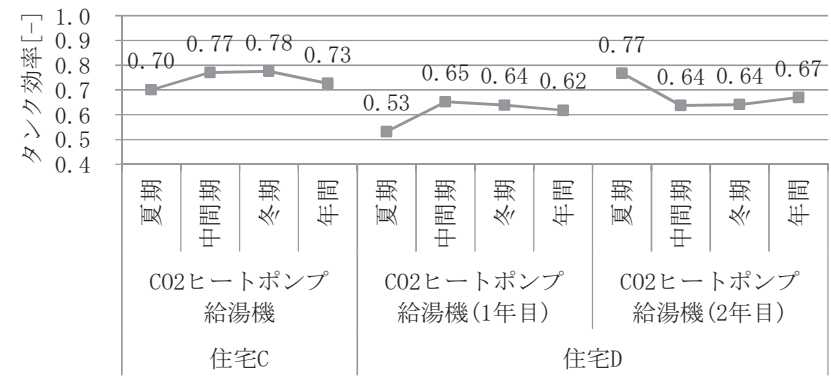

図 16 タンク効率の季節変動

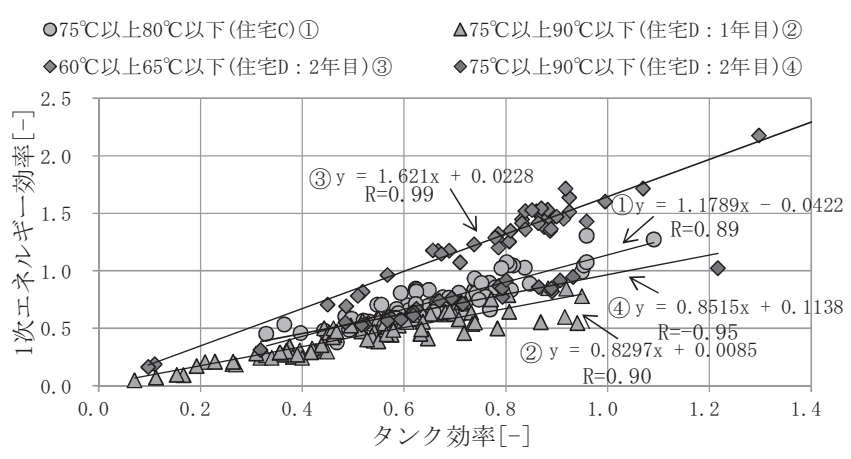

図 17 夏期における HP 稼働時平均出湯温度別の

1 次エネルギー効率とタンク効率との関係

\section{参考文献}

1）経済産業省資源エネルギー庁: エネルギー白書 2009 年度版, 経済産業省資 源エネルギー庁ホームページ, 2009-8-29,

http://www. enecho. meti. go. jp/topics/hakusho/2009energyhtml/index20 09. htm（参照 2011-01-28）.

2) 久保田敏史他 3 名: 寒冷地における潜熱回収型ガス給湯器と $\mathrm{CO}_{2}$ ヒートポ ンプ給湯機の年間効率に関する研究, 日本建築学会技術報告集, 第 16 巻, 第 32 号, pp. $201-204,2010.2$

3) 小澤明也他 他 5 名: 寒冷地における家庭用ガスエンジンコージェネレーシ ヨンシステムの運用時性能評価, 日本建築学会大会学術講演梗概集, D-2 分冊, pp. 1431-1432, 2010.

4）財団法人建築環境・省エネルギー機構: 住宅事業建築主の判断の基準，財 団法人建築環境・省エネルギー機構, 2009-4, http://ees. ibec. or.jp/index. php (参照 2011-04-20).

5) 清水康成 他 5 名: 住宅用貯湯式給湯システムの機器稼働実態と性能評価に 関する研究（その 10）家庭用ガスエンジン・コージェネレーションシステ ムの年間実測結果の解析, 第 25 回エネルギーシステム・経済・環境コンフ アレンス講演論文集, pp. 223-226, 2009.

6）木谷健一 他 4 名:家庭用ガスエンジン・コージェネレーションシステムの 特性分析, 第 25 回エネルギ一資源学会研究発表会講演論文集, pp. 269-272, 2006. 6 .

7) 中濱諒他 3 名:新時代の省エネ型給湯設備の計画・評価手法に関寸る研究 第 5 報 実住戸における湯消費の実測, 日本建築学会大会学術講演梗概集, D-1 分冊, pp. 889-890,2009.8

8) 高田宏 他 5 名:住宅における $\mathrm{CO}_{2}$ ヒートポンプ給湯機の使用実態とその評 価に関する研究 (その 6) 年間データによる $\mathrm{CO}_{2}$ ヒートポンプ給湯機の稼働 実態, 第 26 回エネルギー・資源学会研究発表会講演論文要旨集, pp. 173-176, 2007.6

9) 前真之他 2 名：多様な家族構成を対象とした住宅の給湯消費実態に関す る実測調查 その 1) 世帯人数別の湯消費量, 日本建築学会大会学術講演梗 概集, D-1 分冊, pp. 573-574, 2007.8

10）東京ガス株式会社: 都市ガスの $\mathrm{CO}_{2}$ 排出係数, 東京ガスホームペー ジ, 2010-10-1, http://www. tokyo-gas. co. jp/env/gas/category08. html (参照 2011-01-28). 
11) 経済産業省: エネルギーの使用の合理化に関する法律施行規則, 2010-3-19, 経済産業省ホームページ,

http://law. e-gov. go. jp/htmldata/S54/S54F03801000074. html (参照 2011-01-28).

12）小森尚志 他 3 名: 統計学の基礎と演習, 東海大学出版会, 2006.7

\section{記号表}

$Q_{h w}$ : 湯張り負荷、足し湯負荷、追し焚き負荷、給湯負荷の合計熱量 $[M J / 日]$ $Q_{\text {bath }}:$ 湯張り負荷 $[M J /$ 日]

$Q_{r h}:$ 追い焚き負荷 $[M J /$ 日 $]$

$Q_{G}:$ 排熱・ヒ一夕回收熱量 $[M J /$ 日]

$Q_{s p}:$ 床暖房及び浴室暖房乾燥機の合計放熱量 $[M J /$ 日 $]$

$Q_{H P}:$ ヒートポンプ生産熱量 $[M J / 日]$

$G_{G E}:$ ガスエンジンガス消費量 $\left[\mathrm{m}^{3} /\right.$ 日]

$G_{B U B}:$ 補助ボイラガス消費量 $\left[\mathrm{m}^{3} /\right.$ 日]

$G_{C G W H}$ : 潜熱回收型ガス給湯器ガス消費量 $\left[m^{3} /\right.$ 日]

$W_{G E-C G S, h o u s e}:$ 家庭内消費電力量 $(G E-C G S)[k W h /$ 日 $]$

$W_{P V S, h o u s e}:$ 家庭内消費電力量 $(P V S)[k W h /$ 日]

$W_{G E-C G S, t o t a l}: G E-C G S$ 総発電量 $[k W h /$ 日]

$W_{p e}:$ 購入電力量 $[k W h /$ 日]

$W_{H P}:$ ヒートポンプ稼働時電力消費量 $[k W h /$ 日]

$W_{d f}:$ 除霜運転時電力消費量 $[k W h /$ 日]

$W_{G E-C G S A U X S}: G E-C G S$ 電力消費量 $[k W h /$ 日]
$W_{\text {CGWHAUXS }}$ 潜熱回收型ガス給湯器電力消費量 $[k W h /$ 日]

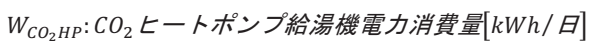

$R_{r h}:$ 追い焚き負荷割合[\%]

$R_{\text {gcr, }, \text { case } 1}:$ 発電寄与率 $(G E-C G S+P V S)[\%]$

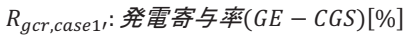

$R_{g c r, c a s e 2}:$ 発電寄与率 $(G E-C G S)[\%]$

$R_{G E-C G S, h o u s e}:$ 家庭内消費電力割合 $[\%]$

$\eta_{\text {epg }}:$ 発電利用效率 $[-]$

$\eta_{e e r}$ : 排熱・ヒータ回收效率-]

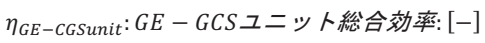

$\eta_{G E-C G S 1}, \eta_{G E-C G S 2}: G E-C G S$ のエネルギー效率[-]

$\eta_{C G W H 1}, \eta_{C G W H 2}$ : 潜熱回収型ガス給湯器のエネルギー効率[-]

$\eta_{\mathrm{CO}_{2} \mathrm{HP}_{1},} \eta_{\mathrm{CO}_{2} \mathrm{HP} 2}: \mathrm{CO}_{2}$ ヒートポンプ給湯機のエネルギー效率—]

a: 都市ガス(天然ガス)のエネルギー換算値 $(H H V)[M J / m]$

$\mathrm{b}:$ 電力の 2 次エネルギー換算值 $[M J / k W h]$

c: 電力の 1 次エネルギー換算値 $[M J / k W h]$

$\mathrm{s}:$ クーラントの比熱 $\mathrm{J} / \mathrm{kg} \cdot \mathrm{K}]$

$h:$ 発電時間[時間/日]

$T_{H P o u t}: H P$ 稼働時平均出湯温度 $\left[{ }^{\circ} \mathrm{C}\right]$

$T_{H P i n}: H P$ 稼働時平均入水温度 $\left[{ }^{\circ} \mathrm{C}\right]$

（2011年 2 月 8 日原稿受理，2011年 7 月 12 日採用決定） 